\title{
Average Bid Method - An Alternative to Low Bid Method in Public Sector Construction Procurement in Nepal
}

\author{
Santosh Kumar Shrestha \\ Department of Civil Engineering, Central Campus, Pulchowk, IOE, TU, Lalitpur, Nepal \\ Corresponding Email: skshrestha1969@gmail.com
}

\begin{abstract}
Federation of Contractor Associations of Nepal (FCAN) has asked the government to amend the law so that bidders quoting the average price would be awarded the contract. The competitive bidding process for awarding construction contracts in Nepal is based on the low bid method. According to this method, the construction firm submitting the lowest bid receives the right to the construction contract. Promoting competition amongst contractors and maintaining transparency are the clear benefits but delays in meeting the contract duration, increment of the final project cost, tendency to compromise quality, and adversarial relationship among contracting parties are the major drawbacks.As alternative of low bid method, some countries are using Average bid method.In this method, contract is awarded to the contractor whose price is closest to the average of all bids submitted. It is assumed that with a fair price they would conform to quality requirements of the project, would complete on time, and would not have adversarial relationships with the consultant of the employer. Awarding tenders to the lowest bidders is the major reason behind lingering construction projects and failure in meeting its standards in Nepal. To avoid such problems, Average bid Award system may be practiced by public agencies for procurement of works in Nepal.
\end{abstract}

\section{Background}

The 16th annual general meeting of the Federation of Contractor Associations of Nepal (FCAN) asked the government to amend the law so that bidders quoting the average price would be awarded the contract. Amid growing problems of low bidding in government projects, contractors also decided to demand that the government formulate a policy that requires the selection of the tender based on average cost and not on lowest cost basis as provisioned in the Public Procurement Act. Article 25 of the Act states that projects must be awarded to the party that bids the lowest.

\section{Low Bid Method}

In the procurement process, a standard practice for many organizations who are interested in using the competitive nature of bidding is to keep procurement costs low. The competitive bidding process for awarding construction contracts is typically based on the low bid method. According to this method, the construction firm submitting the lowest bid receives the right to the construction contract i.e. contract is awarded to the responsive and compliant bidder that is willing to fulfill the terms of the contract for the lowest dollar value.

Currently, the public sector procurement of construction is largely based on the lowest bid awardsystem. The customary practice of awarding contracts to a lowest bidder was established toensure the lowest cost for completing a project. In public construction works, this practice 
isalmost universally accepted since it not only ensures a low price but also provides a way to avoidfraud and corruption (Irtishad, 1993).

There are definite benefits and drawbacks to the low-bid award system. Promoting competitionamongst contractors, compelling contractors to lower their costs, usually through innovation are clear benefits to the process. Inaddition, the process is beneficial specifically to the public sector because of the transparency, animportant criterion of public policy [11]. However, allowing projects to be awardedbased on the least price has inherent flaws. Delays in meeting the contract duration, increment ofthe final project cost due to high variations, tendency to compromise quality, and adversarialrelationship among contracting parties are the major drawbacks associated with low-bid award procedure [7]. Low bid price as the sole award criterion encourages unqualified contractors to submit bids (Herbsman and Ellis, 1992) along with bidders that submit a very low bid with the intent of recovering their losses through change orders and claims, also known as predatory bidding (Crowley and Hancher, 1995). Therefore, low bid is not necessarily the best value.

The major drawback of the low-bid method is the possibility of awarding a construction contract to a contractor that submits either accidentally or deliberately, an unrealistically low bid price. Often, such an occurrence works to the owner's and contractor's detriment by promoting disputes, increased costs, and schedule delays (Ioannou and Leu, 1993). If a contractor submits a bid that is significantly lower than the client's estimate and the other bidders, it is difficult to understand how that contractor could complete the job profitably.

Researchers have summarized the long list of factors that can influence a contractor's decision to bid and the price they submit (Chua, 2000; Fayek, 1998). Imprecise and ambiguous contract documentation (including incomplete drawings) may cause a contractor to make a serious omission in calculating costs. Errors may also arise due to insufficient time to prepare the bid (Zack, 1993). Some bidders carefully review the bid documents searching for mistakes and ambiguity in areas that could lead to change orders and claims during the project (Doyle and DeStephanis, 1990). In all cases, the abnormally low bid is not reflective of the final contract cost or the hidden costs incurred by the client when dealing with numerous change orders and claims.

As per Public Procurement Act Nepal, 2063, contract is awarded to lowest evaluated substantively responsive bid. Generally, the contract is awarded to the lowest bidder, even though according to the bidding document other factors are also to be considered during the bid evaluation. As a consequence, contractors often reduce their bids to uneconomic levels. This will have negative impact on both quality and duration of the project. Awarding tenders to the lowest bidders who put unreasonably low estimate is the major reason behind lingering construction projects and failure in meeting its standards in Nepal.

\section{Alternatives}

As alternative of low bid method, different organizations are using different methods of procurement. In Florida, USA competitive, negotiated bidding is in practice. Under this provision, minimum of three contractors are selected based strictly on their qualifications, and then negotiates a guaranteed maximum price or lump sum (depending on the project) with the highest rated team.The, EU introduced legislation to allow public sector clients the option of awarding a construction project using Economically Most Advantageous Tender (EMAT). It 
enables the contracting authority to take account of criteria that reflect qualitative, technical and sustainable aspects of the tender submission as well as price when reaching an award decision. It is similar to Quality and Cost Based System (QCBS) where certain weightage for Technical and Financial parameters are given and contractor with best contract value is awarded the contract. Some organizations award contract to second lowest bidand the median bid. Several countries, such as Italy and Taiwan, have developed variations of the average bid method.

\section{The Average Bid Method}

In average-bid method, contract is awarded to the contractor whose price is closest to the average of all bids submitted. In general, the winner based on the average bid method is the contractor whose bid satisfies a certain relationship with the average of all bid prices. Different average bid methods use different procedures for calculating the average, or use different criteria for determining the winning bid. For example, some use an arithmetic average or a weighted average, while others use the average of the remaining bids after all bids that differ more than a certain percentage from the average of all other bids are eliminated. Similarly, the winner might be the contractor whose price is closest to the average, or the contractor whose bid is closest to, but less than the average. The former, for example, is used in Taiwan while the latter is used in Italy.

To illustrate the mechanism of the average bid method, consider the example belowwhich shows seven contractors that have submitted the bids.

\begin{tabular}{|l|c|c|c|c|c|c|c|}
\hline Contractor & A & B & C & D & E & F & G \\
\hline Bid Amount & 78 & 85 & 96 & 102 & 105 & 108 & 125 \\
\hline Difference from average & -21.86 & -14.86 & -3.86 & 2.14 & 5.14 & 8.14 & 25.14 \\
\hline$\%$ difference from average & $-21.9 \%$ & $-14.9 \%$ & $-3.9 \%$ & $2.1 \%$ & $5.2 \%$ & $8.2 \%$ & $25.2 \%$ \\
\hline \multicolumn{7}{|c|}{ Average is 99.86} \\
\hline
\end{tabular}

As per Low bid criteria, contractor A with 78 is to be awarded the contract. The average bid price is 99.86. According to Taiwanese method the bid of contractor D i.e. 102 is closest to the average and thus wins the project and according to Italian method the bid of Contractor C i.e. 96 is closest to and lower than average will get the contract.

This standard mechanism is generally used when there are a small number of bidders. Insituations involving larger numbers of bidders, additional rules may be used such as excluding high and low bids from consideration as an attempt to further eliminate outliers. This mechanism is implemented in Switzerland. In above example Contractor A and G are excluded from competition and new average becomes 99.2.

\begin{tabular}{|l|c|c|c|c|c|}
\hline Contractor & B & C & D & E & F \\
\hline Bid Amount & 85 & 96 & 102 & 105 & 108 \\
\hline Difference from average & -14.86 & -3.86 & 2.14 & 5.14 & 8.14 \\
\hline \multicolumn{5}{|c|}{ Average is 99.2} \\
\hline
\end{tabular}

Closest bidder D is awarded. 
There are other sorts of exclusions sometimes used such as in Peru and in the State of New York where the elimination criterion is based on the difference between bids and the average bid. Bids that lie 10 percent below or above the average will be thrown out, as stated in the Peruvian regulations for bidding and contracting for public works (Albano, Bianchi, and Spagnolo, 2006). In the given example, A, B and $\mathrm{G}$ are excluded and average of remaining bid becomes 102.75.

\begin{tabular}{|l|c|c|c|c|}
\hline Contractor & C & D & E & F \\
\hline Bid Amount & 96 & 102 & 105 & 108 \\
\hline Difference from average & -6.75 & -0.75 & 2.25 & 5.25 \\
\hline \multicolumn{5}{|c|}{ Average is 102.75} \\
\hline
\end{tabular}

Closest bidder $\mathrm{D}$ is awarded.

Similarly, a formula to decide a reasonable offer from several competitive bids was developed in Europe,known as "Danish" system, wherein the lowest and highest offers are rejected out right away andthe rest of the offers are only considered (Irtishad, 1993). This formula stands as:

$$
\mathrm{NA}=(\mathrm{NL}+4 \mathrm{~A}+\mathrm{NH}) / 6
$$

In above example, $\mathrm{A}$ and $\mathrm{G}$ are rejected;

$$
\begin{aligned}
& \mathrm{NL}=\text { new lowis } 85 ; \\
& \mathrm{NH}=\text { new highis } 108 ; \\
& \mathrm{A}=\text { average of all offersis } 99.86
\end{aligned}
$$

Hence,

NA i.e. new average $=(85+4 \times 99.86+108) / 6=98.74$
\begin{tabular}{|l|c|c|c|c|c|}
\hline Contractor & B & C & D & E & F \\
\hline Bid Amount & 85 & 96 & 102 & 105 & 108 \\
\hline Difference from new average & 13.74 & -2.74 & 3.26 & 6.26 & 9.26 \\
\hline
\end{tabular}

The bid which is first above this new average i.e. D is then treated as realistic and acceptable.

The basic philosophy behind the average bidding procedure is that the best bid is the one closest to some average, not the lowest, not the highest. These competitive price-based average bidding methods are used mainly to ensure that the contractor is responsible, to avoid contractor-failure, and to reduce disputes and claims. The underlying principle is that the contractors should get a reasonable and realistic price for their work. It is assumed that with a fair price they would conform to quality requirements of the project, would complete on time, and would not have adversarial relationships with the consultant of the employer.

\section{Conclusion}

Awarding tenders to the lowest bidders is the major reason behind lingering construction projects and failure in meeting its standards in Nepal. Finding the right mix alternative 
procurement methods offer opportunities for creativity and cost-savings, but they are certainly not perfect. Any system has its limitations, and any particular project may encounter problems under either the traditional approach or an alternative procurement strategy, with an unhappy owner as the result.However, average bid award methodavoid most of the limitations of low bid method and hence it is advisable to practice this methodby public entity for procurement of works in Nepal.

\section{References}

[1] The Public Procurement Act, 2007, Nepal.

[2] Baral Santosh: Construction Industry of Nepal, Challenges and Opportunities, Newsletter, FCAN, 2009.

[3] Murray B. Stanley: Seven Reasons Competitive Tendering Fails (And What You Can Do About It), Process Excellence Network, 2014.

[4] A Guide on Bid Evaluation, Asian Development Bank, 2010.

[5] Guidelines: Procurement of Goods, Works, and Non-Consulting Services Under IBRD Loans and IDA Credits \& Grants by World Bank Borrowers, The World Bank, Washington, January 2011.

[6] Standard Procedure for Evaluation of Bids for Procurement of Works, Pakistan Engineering Council, March 2009.

[7] Thomas Bedford: Analysis of the Low Bid-Award System in Public Sector Construction Procurement, MSc. Thesis, Graduate Department of Civil Engineering University of Toronto,2009.

[8] Laychluh, Mechegiaw, Performance Study of Lowest Bidder Bid Award System in Public Construction Projects, MSc. Thesis, Addis Ababa University, 2013.

[9] Bob Lohfeld: Will Low-price Contracting Make us all Losers?, Washington Technology Daily Jun 04, 2012.

[10] Association of Colleges - Further Education Library of Procurement, Most economically advantageous tender (MEAT), August 2012.

[11] Photios G. Ioannou, Ann Arbor Sou-SenLeu:Average-Bid Method-Competitive Bidding Strategy: ASCE Journal of Construction Engineering and Management, Vol. 119, No. 1, March 1993.

[12] Wei-Shiun Chang, Bo Chenz Timothy C. Salmon: An Investigation of the Average Bid Mechanism for Procurement Auctions, October 2013. 